\title{
DETERMINATION OF CALCIUM (Ca) AND MAGNESIUM (Mg) CONTENT IN CACAO (Theobroma cacao Linn) FERMENTATION AND NON FERMENTATION BY SPECTROPHOTOMETRY
}

\author{
Wiranda, Sumaryati Syukur, Hermansyah Aziz \\ Program Studi Kimia Pasca Sarjana Universitas Andalas Padang
}

\begin{abstract}
Cacao beans contain many kinds of mineral, magnesium (Mg), calcium (Ca), Zinc (Zn), Phosphor (P) and etc. This study investigated magnesium $(\mathrm{Mg})$ and calcium $(\mathrm{Ca})$ in fermentation and non fermentation cacao beans by atomic absorption spectrophotometry. $\mathrm{Mg}$ and $\mathrm{Ca}$, content in non fermentation cacao beans of green and red variety are $453 \mu \mathrm{g} / \mathrm{g}, 466 \mu \mathrm{g} / \mathrm{g}$, and $491 \mu \mathrm{g} / \mathrm{g}, 445 \mu \mathrm{g} / \mathrm{g}$. $\mathrm{Mg}$ and $\mathrm{Ca}$, contents in fermentation cacao beans of green and red variety are, $596 \mu \mathrm{g} / \mathrm{g}, 528 \mu \mathrm{g} / \mathrm{g}$, and 554 $\mu \mathrm{g} / \mathrm{g}, 505 \mu \mathrm{g} / \mathrm{g}$. Fermentation make magnesium $(\mathrm{Mg})$ and calcium $(\mathrm{Ca})$ content increase significantly.
\end{abstract}

Keywords : Theobroma cacao Linn, fermentation, spectrophotometry.

\section{DAFTAR PUSTAKA}

1. C. Bennet \& F. Hasan, Exports of low quality from Sulawesi, Indonesia; Market failure or market evolution, International Conference on Economy, Bali, Indonesia, 1993.

2. C. Niemenak, S. Rohsius, D. O. Elwers, Ndoumou, and R. Lieberei, Comparative Study of different cocoa (Theobroma cacao $L$.) clones in terms of their phenolics and anthocyanins contents, $J$. of Food Composition and Anal., 19.

3. A. J. Abarca, A Validassed Flame AAS Method For Determining Magnesium in a multivitamin, Pharmaceutical preparation, $J$.
Of Pharmaceutical and Biomedical Anal., 25: 941-945, (2001).

4. A. Apriyantono, D. Fardiaz, N. L. Puspitasari, S. Yasni, S. Budiyanto, Penuntun Praktek Analisis Pangan, Pusat Antar Universitas Pangan dan Gizi, IPB, 1988, 200-203, 303-305.

5. H. D. Belitz, W. Grosch, Food Chemistry, Springer Verlag Berlin Heidelberg New York London Paris Tokyo.01, 16 Februari 2007.

6. Pempropsu, Karakteristik Biji Kakao Kering Hasil Pengolahan Dengan Metode Fermentasi Dalam Karung Plastik, http://www.pempropsu.go.id.php?filename $=$ Biji\%20Kakao\%20Kering.pdf\&id=KA-01 (16 februari 2007). 